\title{
Eccrine Hidrocystoma Arising at the Tarsal Plate during Childhood
}

\author{
Akira Hirata \\ Department of Ophthalmology, Saga University Faculty of Medicine, Saga, Japan
}

\section{Key Words}

Eccrine hidrocystoma $\cdot$ Eyelid $\cdot$ Blepharoptosis $\cdot$ Amblyopia

\begin{abstract}
A 2-year-old boy with an upper-eyelid tumor in his right eye underwent complete resection. Pathological examination showed that the tumor was composed of a thin wall, lined by a single cuboidal epithelium, and contained a transparent liquid. The epithelium of the tumor wall did not display decapitation and the tumor was diagnosed as eccrine hidrocystoma. After resection, obvious improvement of the tumor-caused blepharoptosis was observed and the visual acuity of the patient recovered.

(C) 2013 S. Karger AG, Basel
\end{abstract}

\section{Introduction}

Lid tumors occurring in children are usually congenital and sometimes cause disturbance of the visual development as well as being a cosmetic problem. Hidrocystomas are benign adnexal tumors that may be eccrine or apocrine in origin. Eccrine hidrocystomas are usually small, thin-walled retention cysts that occur in adulthood [1-3]. Only a few cases have been reported in children. Here, we report a case of a boy who presented with an upper-eyelid tumor that led to mechanical ptosis and amblyopia. After excision of the tumor, histological examination confirmed eccrine hidrocystoma.

\section{Case Report}

A 5-month-old boy was referred to us for further examination of his right upper-eyelid tumor. The tumor was $8 \mathrm{~mm}$ in diameter and observed in the upper eyelid (fig. 1a). According to his parents, the tumor was first noticed at the child's birth. As the patient could 
Hirata: Eccrine Hidrocystoma Arising at the Tarsal Plate during Childhood

open his eye, it was assumed that the tumor most likely would not affect the visual development in his right eye. Therefore, at that time, we decided that a follow-up examination was the best option for the patient. However, due to a gradual enlargement of the tumor, the patient returned 2 years later and underwent further evaluation (fig. $1 \mathrm{~b}$ ). At the time of the follow-up examination, the tumor exhibited a distinct boundary and was $12 \mathrm{~mm}$ in size. Physical examination revealed that there was no pain or any inflammatory reaction in the lid. When observed from the side of the palpebral conjunctiva, the tumor was found to be buried beneath a portion of the tarsal plate and showed a translucent configuration (fig. 1c). A T2-enhanced magnetic resonance imaging (MRI) examination demonstrated that the tumor was well demarcated from the surrounding tissue. This uniformly high-intensity lesion was $12 \mathrm{~mm}$ (height) $\times 12 \mathrm{~mm}$ (width) $\times 8 \mathrm{~mm}$ (depth) in size, with the lesion observed to be in direct contact with the tarsal plate (fig. 1d). Since the tumor caused blepharoptosis in the patient's right eye, this subsequently led to oblique astigmatism. Therefore, 2 months later, it was decided to surgically remove the mass lesion. The wall of the tumor was easily separated from the surrounding connective tissues, with the exception of the portion where the tarsal plate was attached. As a result, the tumor was completely removed along with a round defect of the tarsal plate (fig. 1e). Pathological examination showed that the tumor was composed of a thin wall and contained a transparent liquid. The wall consisted of a single cuboidal epithelium that covered the inner luminal surface without decapitation. An area of papillary process proliferation was also observed (fig. 1f). Based on these findings, the tumor was diagnosed as eccrine hidrocystoma. Although there was obvious improvement in the blepharoptosis after the surgery, his best-corrected visual acuities remained at $0.2 \mathrm{OD}$ and $1.2 \mathrm{OS}$ due to the refractive astigmatic amblyopia that was present at 2 weeks after the procedure. Thus, the patient was provided with a prescription for glasses and, with the help of his parents, began a training program designed for the visual recovery of his right eye. Two years later, his best-corrected visual acuities recovered to $1.0 \mathrm{OD}$ (fig. 1g).

\section{Discussion}

Eccrine hidrocystomas usually result from the dilation of cystic excretory eccrine glands due to the retention of sweat in conjunction with the dilation or blockage of the sweat duct [1-5]. Under a microscope, eccrine hidrocystomas appear as unilocular cysts that usually contain a single cystic cavity composed of one or two layers of cuboidal cells. These are located within the mid-dermal to superficial layers of the skin, especially around the eyes. Singh et al. [5] reported findings in 34 patients with hidrocystomas. The mean age at diagnosis was 59 years (range 39-91) and most of the patients (71\%) were found to have only one tumor. Almost all of the tumors $(97 \%)$ were $<10 \mathrm{~mm}$ in size, with the vast majority (75\%) observed to have a maximal diameter of $<5 \mathrm{~mm}$ [5]. At the present time, the study by Nam et al. [4] is the only one to have previously reported a case of eccrine hidrocystoma arising in childhood.

In our current case, the tumor was originally identified at birth as a large cyst that was located in the lid, with adherence to the tarsal plate. Since the tumor, with the exception of the portion where the tarsal plate was attached, could be easily separated from the surrounding connective tissues, the lesion may have arisen from an eccrine gland of an aberrated origin.

Upper-eyelid tumors often cause blepharoptosis and result in amblyopia. Although this case did not lead to this complication, the large-sized tumor arising at birth did affect the corneal curvature, thereby resulting in high astigmatism. From the standpoint of amblyopia 


\begin{tabular}{l|l}
\hline Case Rep Ophthalmol 2013;4:61-63 \\
\hline DOI: $10.1159 / 000354139$ & $\begin{array}{l}\text { @ 2013 S. Karger AG, Basel } \\
\text { www.karger.com/cop }\end{array}$ \\
\hline
\end{tabular}

Hirata: Eccrine Hidrocystoma Arising at the Tarsal Plate during Childhood

prevention, eyelid tumors during childhood need to be cautiously examined and treated properly.

\section{References}

1 Masri-Fridling GD, Elgart ML: Eccrine hidrocystomas. J Am Acad Dermatol 1992;26:780-782.

-2 Sarabi K, Khachemoune A: Hidrocystomas - a brief review. MedGenMed 2006;8:57.

-3 Sperling LC, Sakas EL: Eccrine hidrocystomas. J Am Acad Dermatol 1982;7:763-770.

-4 Nam JH, Lee GY, Kim WS, Kim KJ: Eccrine hidrocystoma in a child: an atypical presentation. Ann Dermatol 2010;22:69-72.

-5 Singh AD, McCloskey L, Parsons MA, Slater DN: Eccrine hidrocystoma of the eyelid. Eye (Lond) 2005;19:7779.
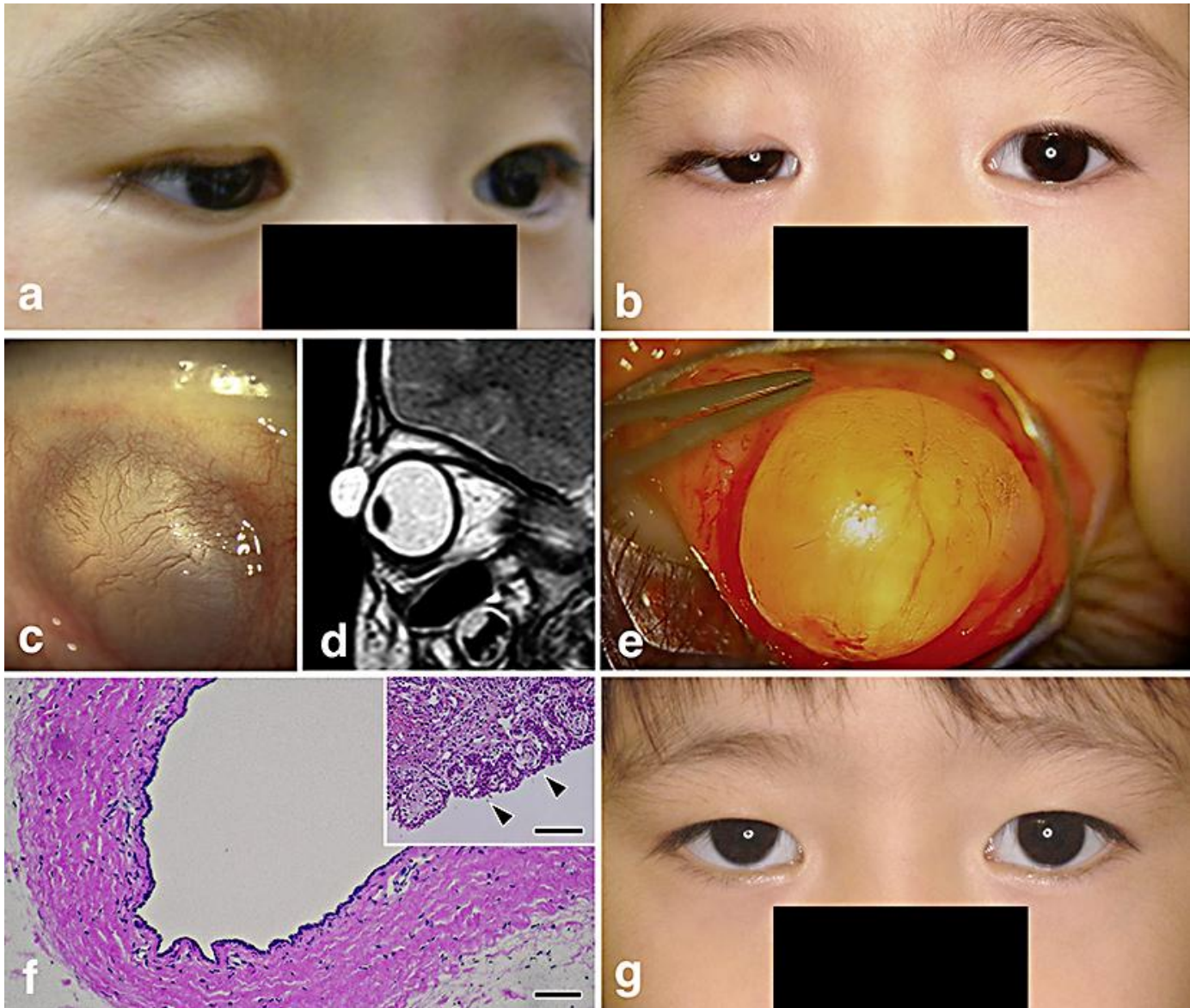

Fig. 1. Clinical features of the patient and pathological findings of the tumor. a Photograph taken at the first visit. A tumor was noted on the upper eyelid. b Photograph taken 2 years later. A gradual enlargement of the tumor was observed. c Slit lamp photograph of the palpebral conjunctiva in the right eye. A translucent tumor wall was seen at the tarsal plate. $\mathbf{d}$ T2-enhanced MRI findings of the tumor. Examination of the right upper eyelid revealed a well-demarcated tumor with liquid that was of a uniformly high intensity. e Intraoperative findings of the tumor. Translucent content was seen through the wall of the tumor. $f$ Pathological findings of the tumor. The wall was lined by single cuboidal epithelium. This epithelium did not show decapitation. Bar: $300 \mu \mathrm{m}$. In addition, an area of papillary process proliferation was also observed (inset, arrowheads; bar: $200 \mu \mathrm{m}$ ). g Photograph at 6 months after the surgery. An obvious improvement of the blepharoptosis was noted. 